\title{
The Challenges of Industrial Revolution 4.0: The Role of Leadership of Kyai in Islamic Boarding Schools
}

\author{
Munif Muhammad Zuhri ${ }^{1}$ Fathur Rokhman ${ }^{2} \quad$ Agus Nuryatin $^{2} \quad$ Tri Joko Raharjo ${ }^{2}$ \\ 1.Pondok Pesantren Giri Kusumo, Semarang, Indonesia \\ 2.Universitas Negeri Semarang, Semarang, Indonesia
}

\begin{abstract}
This research is motivated by the industrial revolution 4.0, which affects various fields, one of which is education. Education in Islamic boarding schools that learns about knowledge and religious skills is one of ones affected by the industrial revolution 4.0. A leader, namely Kyai, who manages a boarding school, will lead to organizational development accompanied by a transformational leadership style. This research is a conceptual study that aims to increase references and produce a proposition on Kyai's transformational leadership research in Islamic boarding schools. Based on the previous literature, it can be concluded that transformational leadership affects infrastructure support in education. In addition, transformational leadership can create a comfortable organizational environment. Transformational leadership maintains cultural and religious values in Islamic boarding schools and transformational leadership styles lead to an increase in students' character education. This research can be used as a study to deepen further research.
\end{abstract}

Keywords: Transformational Leadership, Islamic Boarding School, Kyai, Santri

DOI: $10.7176 / \mathrm{EJBM} / 13-22-06$

Publication date: November $30^{\text {th }} 2021$

\section{Background}

An organization is a place for a group of people to carry out certain activities following goals that have been set. In achieving their goals, organizations have management principles that can be applied to support them in attaining efficient and effective goals (Mafabi et al., 2012). Management of an organization requires a fixed strategy to achieve goals so that all human resources and organizational resources in the form of infrastructure can be utilized optimally (Zhang et al., 2020). Human resources and other organizational resources require management which is based on management principles to produce an activity that supports the goal to be successful. An organization needs a leader as a coordinator in carrying out activities to achieve the goals that have been set (Al Mehrzi \& Singh, 2016). The function of a leader is needed in the organization to direct the activities under organizational planning. A leader not only functions as a symbol of harmony in the organization, but also plays a role in directing the achievement of goals. The function of a leader is as a guide in achieving goals and planning according to the infrastructure owned by the organization (Ibrahim \& Daniel, 2019).

Nowadays, Islamic boarding schools are educational institutions that play an important role in providing moral and religious education to the community. The focus of Islamic boarding schools is to provide education to the younger generation as the nation's next generation to have a high level of morality and religiosity to be partly responsible in society according to their respective capacities (Kesuma, 2017). Moral education is an essential aspect of society and is needed to build a civilized society in building a nation. Morality is an important fundamental in the life of the country and state. Knowledge without morality will lead to unmatched progress by humanism and harmony (Susanto, 2017). The religiosity produced by graduates of Islamic boarding schools will lead to people who are obedient to religion and hold fast to their faith. The vital function of Islamic boarding schools for the community requires a leader who is able to manage an educational organization, named Islamic boarding schools, that is under the rules of learning without abandoning the religious teachings (Ajan et al., 2018).

The current era is an advancement marked by rapidly developing technology. The industrial revolution 4.0 led to technological advances that relied not only on electronic equipment such as computers, cell phones, and other equipment, but the internet also brought significant changes, one of which was in the field of education (Kurniawan, 2018). Islamic boarding schools as educational institutions have an essential role in filtering technology in the industrial revolution 4.0 to become a valuable medium in educating students. Industrial revolution 4.0 certainly brings changes in carrying out the learning process in Islamic boarding schools with the purpose that the role of a leader to direct an Islamic boarding school in facing the industrial revolution 4.0 is very necessary. At the moment, the method of accepting or filtering technology is fundamental to be played by the leaders of Islamic boarding schools (Safi i, 2020).

Leaders of Islamic boarding schools in the industrial revolution 4.0 faced challenges related to technological developments. The challenge was to adapt education to the era of technology that is currently developing. A leader would undoubtedly provide opportunities for students to be well-understood about technological changes so that with the equipped understanding, students will be able to compete in the current development (Lawrence et al., 2019). Another challenge was to continue to adhere to religious principles and Islamic teachings to filter out good 
technology and minimize the negative impacts of these technological changes to a minimum. This study aims to explore the role of a leader in facing the era of the industrial revolution 4.0 concerning education in Islamic boarding schools conceptually. The role of a leader in Islamic boarding schools is vital in facing this industrial revolution. This research can be used as a literature review to analyze important aspects of Kyai's leadership in Islamic boarding schools.

\section{Methodology}

This study used conceptual analysis to explore studies related to Kyai leadership to analyze the factors related to leadership and their implications (Sekaran \& Bougie, 2016). This study aims to explore the essential aspects that need to be considered in coordinating and directing Islamic boarding schools, especially social dynamics. This research explores previous research through Google Scholar to analyze studies related to Kyai's leadership in Islamic boarding schools. The steps taken are by exploring the keywords related to Kyai's leadership to obtain sufficient data. If you have found previous research studies, the findings were arranged to be a summary and conclude the research results to be combined with the results of other studies.

\section{Results}

Technology development is required in the process of improving the quality of education in Islamic boarding schools. The result of this technology is based on various aspects that can be improved, such as laboratories in Islamic boarding schools and the level of internet connections that can be used to surf in cyberspace (Bashori, 2019). Students' skills will increase with an understanding that is in accordance with globalization. These skills can be obtained by introducing various fields of learning based on the industrial revolution 4.0. In the current era, students can gain knowledge from multiple areas through the internet, which is provided to acquire new knowledge The role of a leader is to provide opportunities for Islamic boarding schools to open themselves up in obtaining these technologies. A leader will have foresight about the knowledge that students must acquire in gaining new insights through technology. A leader who has a transformational style will seek to bring about recent organizational changes, namely Islamic boarding schools (Barrick et al., 2015). A Kyai with a transformational leadership style likes significant new developments in the educational process. This leader tries new things and is not discouraged by the challenges he faces. A Kyai with a transformational leadership style will change the point of view of a challenge into hope. The transformational leadership style implemented in Islamic boarding schools will lead to progress since the students gain exposure to the technology they master, they can obtain cognitive, affective, and psychomotor insights (Othman et al., 2014). The acquisition process of the three aspects, namely cognitive, affective and psychomotor, requires adequate infrastructure so that the Kyai's management ability to manage Islamic boarding schools by expecting changes will have more profound implications. The infrastructure provided will lead to significant changes so that the opportunities provided by a leader, the Kyai, with his transformational leadership style, can be applied in an implementation manner using the adequate educational infrastructure. Transformational leadership in Islamic boarding schools will lead to significant changes (Kesuma, 2017). Moreover, a transformational leader likes changes that lead to excellent and improved education quality in Islamic boarding schools. A leader with a transformational leadership style tries new things while maintaining the existing culture. This kind of leadership style wants to try something that is felt to bring about significant changes, especially with the use of technology by using the internet. Kyai's leadership style with these changes has led to the ability of Islamic boarding schools to keep up with the times without leaving the culture that has been built for a long time (Valckx et al., 2020). However, there are obstacles encountered by a leader with a transformational style, infrastructure barriers. Educational infrastructure is a medium that can be used to enhance the quality of education, one of which is with computers and the internet, which later the learning process that adopts technological developments can support the ability of students to carry out the learning process (Akbar \& Imaniyati, 2019). If a leader with a transformational style is not supported by adequate infrastructure, it is difficult to implement his leadership style. Previous research has shown that educational infrastructure can form an exciting learning process with a pleasant learning experience. Significant changes can be achieved with adequate educational technology, such as computer and internet infrastructure. Nowadays, modern Islamic Boarding Schools, which were developing a lot, were supported by changes in leadership styles and infrastructure in educational technology (Muhibah, 2016).

Proposition 1: The transformative leadership of Kyai in Islamic boarding schools and the use of technology in education is effective when accompanied by adequate educational infrastructure.

Transformational leadership is a form of leadership style that provides changes to the current culture. It seeks to move forward to create effective change as an organization (Noor, 2019). Kyai is a central figure in Islamic boarding schools to develop comfort in the organizational environment, especially in education. Kyai provides opportunities for corporate members to create a comfortable environment so that the organization's goals, Islamic boarding schools, can be achieved. Transformational leadership aims to provide better change by creating comfortable situations and conditions for all organization members, namely teachers and students who are taking 
part in learning (Novitasari \& Asbari, 2020). ransformational leadership facilitates the process of accepting new ideas that are suitable for Islamic boarding schools.

Kyai, who has a transformational leadership style, can identify themselves as agents of change who can create novelty in Islamic boarding schools (Zulkarnaen et al., 2020). In the current era of technology and industrial revolution 4.0, these novelties need to be created to improve the quality of learning and modernization of Islamic boarding schools that will develop graduates who follow the demands of the times (Bashori, 2019). In addition, a Kyai with a transformational leadership style will try to maintain the culture and religious teachings that can guide graduates of Islamic boarding schools to become Santri according to the demands of the times with good morals (Arif \& Muhammad, 2015). ransformational leadership leads to organizational change, mainly the renewal of newness in various fields and environments. A comfortable environment will bring comfort to all organization members in achieving their work and activities (Susanto, 2017). This achievement process requires motivation that comes from a leader with a characteristic transformational style. Motivation could improve organizational members' quality of services and activities in creating a conducive environment in Islamic boarding schools (Valckx et al., 2020). The figure of Kyai is a central figure in Islamic boarding schools in creating a comfortable environment for members of the organization.

Proposition 2: Transformative leadership creates a comfortable organizational environment for organizational members.

Leaders with a transformational style strive to maintain a good culture in Islamic boarding schools. These cultures will be developed under the characters that exist in the community. A leader with a transformational style acts on values based on humanism, harmony and other aspects that maintain togethernes (Wasito, 2021). Transformational leadership is a leader who uses a leadership style by acting on a value system, meaning that this kind of leader tries to change things that are not beneficial for the better while maintaining basic values (Verawati Wote \& Patalatu, 2019). Organizational culture is an important part of the organization that leaders constantly maintain with transformational characteristics. The existence of a transformational leadership style leads to changes and a coordinated organization that contributes to an increase in service quality. An organization led by a Kyai with a transformational style will form cultural conservation, which is expected to bring about change and maintain the morale of all members of the organization (Hayana \& Wahidmurni, 2019).

The actions of transformational leaders based on culture will set about cultural conservation (Affandi M, 2012). ultural conservation is used to maintain an organizational culture that already existed and lead to positive organizational changes in such a way that the presence of a transformational leader will bring togetherness in the process of achieving the organizational goals (Aziz \& Taja, 2016). A Kyai has a central role in maintaining and conserving culture to preserve noble values. The process of cultural conservation requires effective and efficient efforts in addition to the inclusion of foreign cultures from abroad. Transformational leadership seeks to conserve this culture.

Proposition 3: Transformative leadership maintains cultural and religious values in Islamic boarding schools The transformational leadership style leads to the conservation of the character of the students. The vision and mission of a transformational leader will increase the values of moral conservation for students in Islamic boarding schools. The role of the central kyai in improving the morals of students is the main thing so that it can encourage the improvement of character education in Islamic boarding schools (Safi i, 2020). boarding school is an educational institution that aims to create students who have knowledge based on morals following cultural values (Fadil, 2020). A Kyai understands that a person's success is not only determined by knowledge or skills but also needs to be accompanied by an understanding of the culture and the morals and character of the Santri. Character is the key to improving the graduates' quality so that a Santri who graduates will have high religious values. The ability of students to preserve culture and have superior character will encourage the creation of a civilized society (Pramitha, 2020). Santri who have entered the community will bring changes that lead to the appropriate morals and morals of the community. Transformational leaders work hard to ensure that graduates of Islamic boarding schools can have characters in accordance with the norms that exist in society, for that reason, by equipping students with knowledge and character education, it will produce graduates who are competitive and efficient. Transformational leaders pay attention to the education of students and concentrate on the values of cultural conservation and the ability of students to understand religious teachings (Ajan et al., 2018). Transformational leaders strive to ensure that all students can understand well the character education which is a provision in education. Character education is crucial to provide a view related to morals and humanity.

Proposition 4: Transformative leadership leads to an increase in the character education of students in Islamic boarding schools

\section{Conclusion}

Based on the background with the industrial revolution 4.0, the leadership of Kyai in Islamic boarding schools plays a big role in facing these challenges. Kyai's transformational leadership is an important part of managing the organization, Islamic boarding schools, to face the obstacles of the industrial revolution 4.0 era. As with modern 
Islamic boarding schools, infrastructure in education can support service quality by enhancing knowledge to students. Transformational leadership creates a comfortable organizational environment. The leadership style affects the organizational culture, so Kyai's leadership style will lead to changes in the boarding school with the comfort in the organization. The transformational leadership style will maintain cultural values because a leader acts based on the values espoused in the organizational culture. Kyai's leadership style also influences the character education of students in Islamic boarding schools, with the intention that this leadership style opens up opportunities for planting better character education.

\section{Referensi}

Affandi M, F. (2012). POLA KEPEMIMPINAN KYAI DALAM PENDIDIKAN PESANTREN ( Penelitian di Pondok Pesantren As- syi ’ ar Leles ). Jurnal Pendidikan Universitas Garut, 06(01).

Ajan, A., Mahrudin, A., \& Mulyana, M. A. (2018). Efektivitas Kepemimpinan Karismatik Kyai Dalam Meningkatkan Kinerja Guru the Effectiveness of Kyai Kharismatic Leadership in Improving Teacher Performance. Tabir Muwahid.

Akbar, L., \& Imaniyati, N. (2019). Gaya Kepemimpinan Transformasional Kepala Sekolah Terhadap Kinerja Guru. Jurnal Pendidikan Manajemen Perkantoran, 4(2). https://doi.org/10.17509/jpm.v4i2.18012

Al Mehrzi, N., \& Singh, S. K. (2016). Competing through employee engagement: a proposed framework. International Journal of Productivity and Performance Management. https://doi.org/10.1108/IJPPM-022016-0037

Arif, I., \& Muhammad, A. (2015). Kepemimpinan kyai dalam membentuk etos kerja santri. Jurnal MD, Juli-Des.

Aziz, H., \& Taja, N. (2016). Kepemimpinan Kyai dalam Menjaga Tradisi Pesantren (Studi Deskriptif di Pondok Pesantren Khalafi Al-Mu'awanah Kabupaten Bandung Barat). In Ta'dib : Jurnal Pendidikan Islam (Vol. 5, Issue 1)

Barrick, M. R., Thurgood, G. R., Smith, T. A., \& Courtright, S. H. (2015). Collective organizational engagement: Linking motivational antecedents, strategic implementation, and firm performance. Academy of Management Journal. https://doi.org/10.5465/amj.2013.0227

Bashori, B. (2019). KEPEMIMPINAN TRANSFORMASIONAL KYAI PADA LEMBAGA PENDIDIKAN ISLAM. AL-TANZIM : JURNAL MANAJEMEN PENDIDIKAN ISLAM, 3(2). https://doi.org/10.33650/altanzim.v3i2.535

Fadil, F. (2020). Evaluation of Input, Process, and Outputs of Ma'had Ali Program in Islamic Boarding School. Ta'allum: Jurnal Pendidikan Islam, 8(1). https://doi.org/10.21274/taalum.2020.8.1.119-138

Hayana, N., \& Wahidmurni, W. (2019). Kepemimpinan Kyai Dalam Memberdayakan Kewirausahaan Santri. JMPI (Jurnal Manajemen Pendidikan Islam), 4(1). https://doi.org/10.18860/jmpi.v4i1.7223

Hilman, H., \& Abubakar, A. (2019). Establishing a highly competitive university: A strategic management perspective. Journal for Global Business Advancement, 12(1). https://doi.org/10.1504/JGBA.2019.099924

Ibrahim, A. U., \& Daniel, C. O. (2019). Impact of leadership on organisational performance. International Journal of Business Management and Social Research, 6(2). https://doi.org/10.18801/ijbmsr.060219.39

Kesuma, G. C. (2017). Pesantren Dan Kepemimpinan Kyai. Terampil : Jurnal Pendidikan Dan Pembelajaran Dasar. https://doi.org/10.24042/TERAMPIL.V1I1.1308

Kurniawan, A. (2018). PENGARUH KEPEMIMPINAN KHARISMATIK KYAI DAN MOTIVASI ORANG TUA TERHADAP ETOS BELAJAR SANTRI STUDI KASUS ATAS PONDOK PESANTREN 'AINURRAFIQ KUNINGAN. JIEM (Journal of Islamic Education Management). https://doi.org/10.24235/jiem.v2i2.3621

Lawrence, R., Ching, L. F., \& Abdullah, H. (2019). Strengths and weaknesses of education 4.0 in the higher education institution. International Journal of Innovative Technology and Exploring Engineering, 9(2S3), 511-519. https://doi.org/10.35940/ijitee.B1122.1292S319

Mafabi, S., Munene, J., \& Ntayi, J. (2012). Knowledge management and organisational resilience: Organisational innovation as a mediator in Uganda parastatals. Journal of Strategy and Management. https://doi.org/10.1108/17554251211200455

Muhibah, S. (2016). KEEFEKTIFAN KEPEMIMPINAN KYAI PADA PONDOK PESANTREN. ALQALAM, 33(2). https://doi.org/10.32678/alqalam.v33i2.394

Noor, M. (2019). Gaya Kepemimpinan Kyai. Jurnal Kependidikan, 7(1). https://doi.org/10.24090/jk.v7i1.2958

Novitasari, D., \& Asbari, M. (2020). Peran Kesiapan untuk Berubah terhadap Kinerja Guru di Masa Pandemi Covid-19. Journal of Industrial Engineering \& Management Research (JIEMAR), 1(2).

Othman, A., Talib, O., Hassan, S. A., \& Kamarudin, N. (2014). Cognitive, Afective and Students' Performance : A Model of Meaningful Learning. Seminar Penyelidikan \& Pembangunan Sumber Manusia 2014.

Pramitha, D. (2020). Kepemimpinan kyai di pondok pesantren modern: Pengembangan organisasi, team building, dan perilaku inovatif. Jurnal Akuntabilitas Manajemen Pendidikan, $8(2)$. https://doi.org/10.21831/jamp.v8i2.33058 
Safi i, I. (2020). Model Kepemimpinan Kyai dalam Membentuk Santri Mandiri Di Era 4.0. Al-Mada: Jurnal Agama, Sosial, Dan Budaya, 3(2). https://doi.org/10.31538/almada.v3i2.656

Sekaran, U., \& Bougie, R. (2016). Research methods for business : a skill-building approach / Uma Sekaran and Roger Bougie. In Nucleic Acids Research.

Susanto, E. (2017). Kepemimpinan (Kharismatik) Kyai dalam Perspektif Masyarakat Madura. Karsa.

Valckx, J., Vanderlinde, R., \& Devos, G. (2020). Departmental PLCs in secondary schools: the importance of transformational leadership, teacher autonomy, and teachers' self-efficacy. Educational Studies, 46(3). https://doi.org/10.1080/03055698.2019.1584851

Verawati Wote, A. Y., \& Patalatu, J. S. (2019). Pengaruh Gaya Kepemimpinan Transformasional dan Kepuasan Kerja terhadap Kinerja Guru Sekolah Dasar. Jurnal Ilmiah Sekolah Dasar, 3(4). https://doi.org/10.23887/jisd.v3i4.21782

Wasito, E. (2021). Pengaruh Komitmen Organisasional terhadap Kinerja Guru Dimoderasi oleh Kepemimpinan Transformasional Kepala Sekolah dan Lingkungan Kerja di SMK .... JIIP-Jurnal Ilmiah Ilmu Pendidikan.

Zhang, X., Lin, Z., Liu, Y., Chen, X., \& Liu, D. M. (2020). How do human resource management practices affect employee well-being? A mediated moderation model. Employee Relations. https://doi.org/10.1108/ER-082019-0320

Zulkarnaen, Z., Supriyati, Y., \& Sudiarditha, I. K. R. (2020). Pengaruh budaya sekolah, gaya kepemimpinan transformasional, dan motivasi kerja terhadap kinerja guru SMK. Jurnal Akuntabilitas Manajemen Pendidikan, 8(2). https://doi.org/10.21831/jamp.v8i2.33867 